\title{
SCREENING OF EXOTIC AND INDIGENOUS APPLE ROOTSTOCKS FOR DIFFERENT HORTICULTURAL TRAITS
}

\author{
K. K. Srivastava", D. B. Singh, Dinesh Kumar and J. I. Mir \\ ICAR-Central Institute of Temperate Horticulture, Old Air Field \\ Rangreth, Srinagar, J \& K-190 007, India
}

\begin{abstract}
An experiment was carried out to find the suitable exotic as well as indigenous apple rootstocks for temperate zone of India. The rootstocks were screened on the basis of 11 important pomological traits. The data revealed that maximum numbers of primary and secondary roots were noted of 93.40, 92.76 in MM.106 and USA 106 and 92.0 noted in CITHrootstock-01, respectively. Maximum length of primary roots $(19.83 \mathrm{~cm})$ was recorded of EMLA 106 whereas shortest primary roots $(6.47 \mathrm{~cm})$ were recorded of ALNARP. The longest secondary roots $(11.83 \mathrm{~cm})$ were found in M.27 and shortest secondary roots $(2.10 \mathrm{~cm})$ in ALNARP rootstock. Most of the indigenous apple rootstocks were having short to medium length of secondary roots. Leaf area was recorded highest $\left(3.80 \mathrm{~cm}^{2}\right)$ in CITH-Apple rootstock-04 and smallest $\left(1.96 \mathrm{~cm}^{2}\right)$ of USA106. All the evaluated rootstocks have pink colored petiole except B-9, which has dark red color. Highest collar rot incidence was observed in M27 and M-26 and least in indigenous root stocks (CITH-Apple rootstocks). Highest wooly aphid infection was found in M-9, B-9, M-27, EMLA-106 and ALNARP whereas least infestation noted in M-26 and indigenous apple rootstock (CITH-ARS-01, CITH-ARS-02, CITH-ARS-03, CITH-ARS-04, CITH-ARS-, CITH-ARS-09 and CITH-ARS-10). Primary root length has positive correlation with secondary root numbers, secondary root length and leaf petiole length but negative correlation with leaf area.
\end{abstract}

Keywords: Apple, rootstock, Malling, CITH-Apple-Rootstock, horticultural traits, Malus baccata

\section{INTRODUCTION}

Apple (Malus $x$ domestica Borkh) being the leading table fruit in the world is considered as the king of temperate fruits. Attractive appearance and longer shelf life

\footnotetext{
* Corresponding author email: kanchanpom@gmail.com
} 
at ambient temperature conditions are its good quality attributes. Most of the apple acreage is at the hill slopes except in the Kashmir valley and a limited area in the Kullu Valley. Unlike other fruits, apple can be grown successfully under sod culture, provided that additional nutrient application than recommendation is supplied to the apple plants to avoid nutrient competition between grass and apple trees. China is the world's leading producer of apple which produces about 55\% of total world's production (76,378,700 tons) other leading countries are USA, Turkey, Poland, India and Italy (FAO, 2014). India produces 2.49 million tones with average production of 7 to $8 \mathrm{t} \mathrm{ha}^{-1}$, though Jammu and Kashmir recorded highest productivity $\left(10.2 \mathrm{t} \mathrm{ha}^{-1}\right)$, (Anonymous, 2014), which is still low as compared to Austria, Switzerland (60-84 t

$\mathrm{ha}^{-1}$ ). Many factors affect the production of apple but rootstock, variety, orchard floor management, planting density, canopy managements are important factors apart from various biotic and abiotic stresses. In Europe lot of research on cultivars and rootstock development has been carried out, which has not influenced the tree size and planting density but has also improved fruit yield and quality. Introduction of exotic rootstocks in India from Europe has proved as a momentum to revolutionize the apple cultivation. These exotic rootstocks have not been evaluated on the basis of horticultural traits. The crab apple (Malus baccata) is abundant flowering and fruiting trees with good number of bold and viable seeds, small leaves and colored small fruits, commonly called as trel in Kashmir. To raise the rootstocks, seeds from processing units are used which are not of same type therefore showed high variability. In view of aforementioned facts, collection and documentation of Malus baccata genotypes were made and 6 collected strains along with exotic Malling series rootstocks were evaluated on the basis of horticultural traits to identify the most sailable rootstocks.

\section{MATERIALS AND METHODS}

The present investigation was carried out during 2009 to 2011 at Central Institute of Temperate Horticulture, Srinagar, Jammu and Kashmir, India, which is situated at latitude of $34^{\circ} 45^{\prime} \mathrm{N}$ and longitude of $74^{\circ} 50^{\prime} \mathrm{E}$ and an elevation of $1649 \mathrm{~m}$ mean sea level. Nine exotic rootstocks (MM- 106, MM-111, M- 9, B-9, M-27, M-26, EMLA-106, USA-106, ALNARP) from introduction and six indigenous rootstocks selections of Malus baccata CITH-ARS-01, CITH-ARS-03, CITH-ARS-04, CITHARS-05, CITH-ARS-09, CITH-ARS-10) selected from Kashmir valley were evaluated in this study. Seedlings were raised from seeds of selected fruits and scions were grafted on wild apple tree also. The selected rootstocks were evaluated for important horticultural traits i.e., primary root numbers, , primary root length $(\mathrm{cm})$, secondary root number and length, leaf area $\mathrm{cm}^{2}$, leaf petiole length, burr knot character, petiole color, leaf attitude to the shoot. Ten plants per replications were selected for recording the observations. The seedling rootstocks of CITH-Apple-Root stocks and the well rooted 2 years old plants of exotic root stocks were uprooted in the October and washed thoroughly in plain water to record the observations. The 
primary and secondary root numbers were counted visually and their lengths were measured with the help of digital vernier caliper, leaf area $\left(\mathrm{cm}^{2}\right)$ recorded with the help of leaf area meter, burr -knot characters observed visually and petiole color recorded using the color chart, leaf attitude in relation to the shoot noted as per apple DUS test guideline available at Protection of Plant Varieties and Farmers Right Authority Official website (Anon, 2016). The disease intensity recorded by disease grading scale as 0 (No Disease), 1(1-10\% disease intensity), 2 (11-20), 3-(21-30), $4(31-30 \%), 5(51-100 \%)$ and the wooly aphid insect incidence as 1-5 point scale as $1(1-20 \%$ foliage damage), 2(21-40\%), 3(41-60\%), 4(61-80\%) and 5(81-100\%). The experiment was laid out in randomized block design comprising three replications with ten plants per replication. Three years data were pooled, analyzed using S-plus statistical software, and presented in graphical form for interpretation of the results.

\section{RESULTS}

Numbers of primary roots varied from 9 to 37.77 of the CITH-AppleRootstock, whereas varied from 40.0 to 93.4 in the exotic rootstocks. Significantly highest numbers of primary roots were recorded for exotic rootstocks i.e., MM-106 (93.40) and USA- 106 (92.67) and CITH-ARS-09 and 04 (37.77 and 37.67). Lowest numbers of primary roots were recorded for indigenous rootstocks i.e. only 9.0 for CITH-ARS-05 and 16.67 for CITH-ARS-01 and 40.33 for ALNARP (Figure 1). Significant variations were found among the evaluated root stocks regarding length of primary roots. Longest primary roots were recorded of EMLA-106(19.83) followed by CITH-ARS-03 $(18.08 \mathrm{~cm})$, whereas shortest primary roots $(6.47 \mathrm{~cm})$ were recorded of ALNARP and M-9 rootstocks (Figure 2). In contrast the highest number of secondary roots (92.0) were noted in CITH-ARS-01 followed by M-26 (73.67) and M 27 (70.54), however, least number of secondary roots were recorded for ALNARP (16.33) and CITH-ARS-05 (35.67) (Figure 3). The longest secondary $(11.83 \mathrm{~cm}$ ) roots were found in M-27 followed by MM106 $(8.39 \mathrm{~cm})$ and CITH-ARS$01(8.32 \mathrm{~cm})$, however shortest secondary roots were found of ALNARP $(2.10 \mathrm{~cm})$ followed by USA-106 $(2.57 \mathrm{~cm})$ (Figure 4$)$. Length of the secondary roots of CITHARS- were found to be smaller to medium in size. 


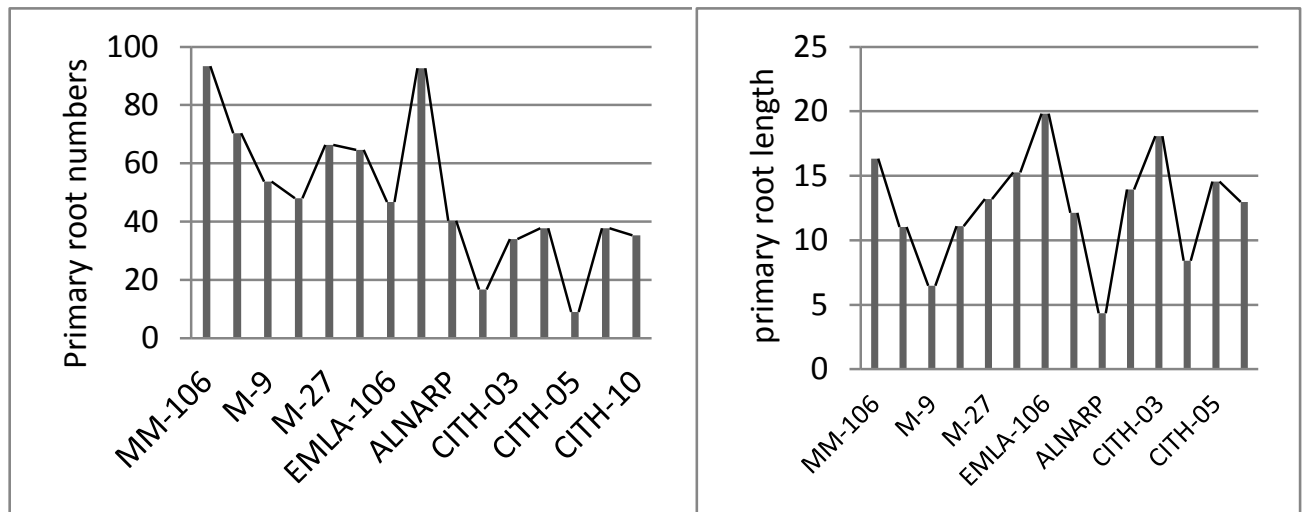

Figure 1. Primary root numbers in apple Figure 2. Primary root length in apple rootstocks rootstocks
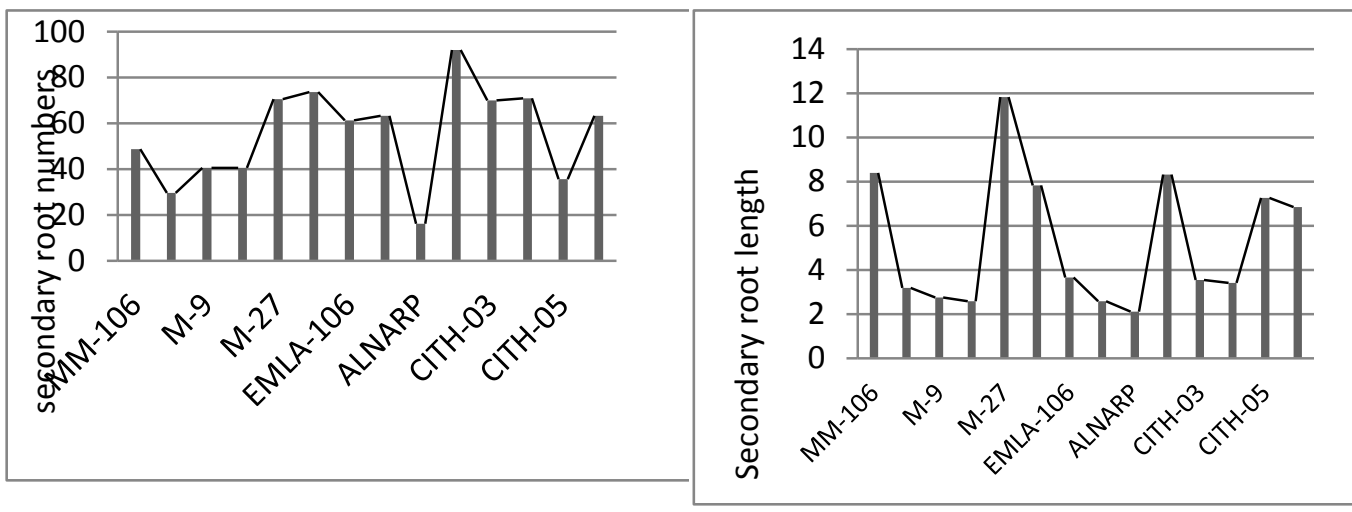

Figure 3. Secondary root numbers in apple rootstock

Figure 4. Secondary root length in apple rootstocks

Leaves are considered as the factory for photosynthesis therefore their area plays important role for rate of photosynthetic reactions ultimately leading to plant growth and development. Maximum Leaf area $\left(3.80 \mathrm{~cm}^{2}\right)$ was recorded of CITHARS-04 leaves closely followed by CITH-ARS-03 $\left(3.56 \mathrm{~cm}^{2}\right)$. Whereas minimum leaf area was recorded of leaves of USA-106 $\left(1.96 \mathrm{~cm}^{2}\right)$ followed by MM-106 rootstock $\left(2.04 \mathrm{~cm}^{2}\right)$ (Figure 5). The length of leaf petioles were found maximum $(26.85 \mathrm{~mm})$ in MM-106 closely followed by MM-111(26.82 $\mathrm{mm})$, shortest leaf petiole $(12.89 \mathrm{~mm})$ found in CITH-ARS-01 and CITH-ARS-04 (13.41mm) (Figure-6). Larger area of leaves helps to increase more sites for photosynthesis and production of growth promoting substances (auxins). Similarly more number of roots (primary and secondary) and their larger area enables plants to absorb nutrients more effectively. These attributes ultimately results in growth promotion as found in this study. 


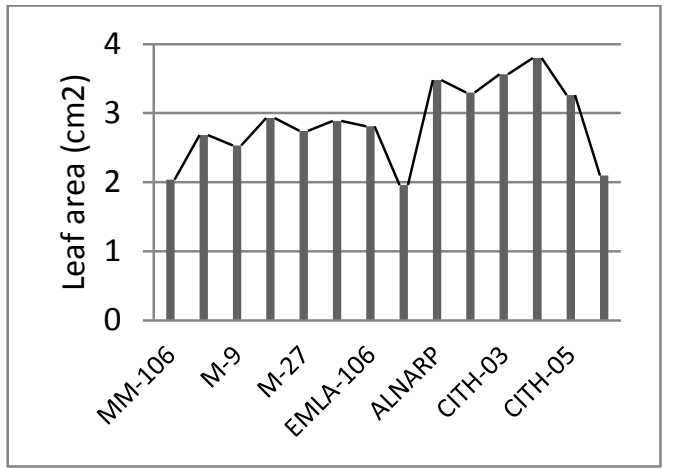

Figure 5. Leaf area in apple rootstocks

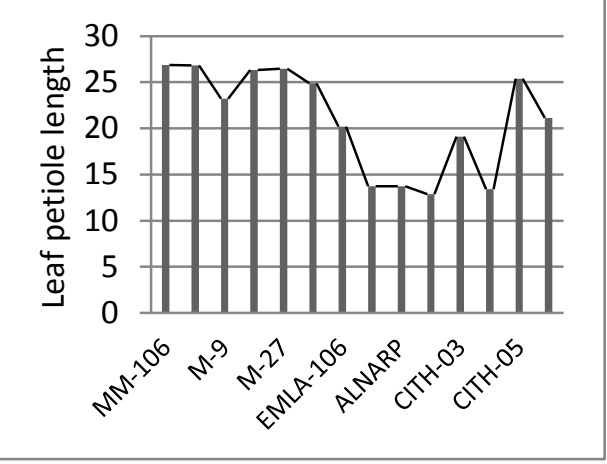

Figure 6. Leaf petiole length of apple rootstocks

Highest collar rot incidence were found in M-27 and M-26 and least in CITH-Apple rootstocks and wooly aphid infection was found M-9, B-9, M-27, EMLA-106 and ALNARP, whereas least was found in M-26, CITH-ARS-01, CITH-ARS-02, CITHARS-03, CITH-ARS-04, CITH-ARS-05, CITH-ARS-09 and CITH-ARS-10 (Figure 7).

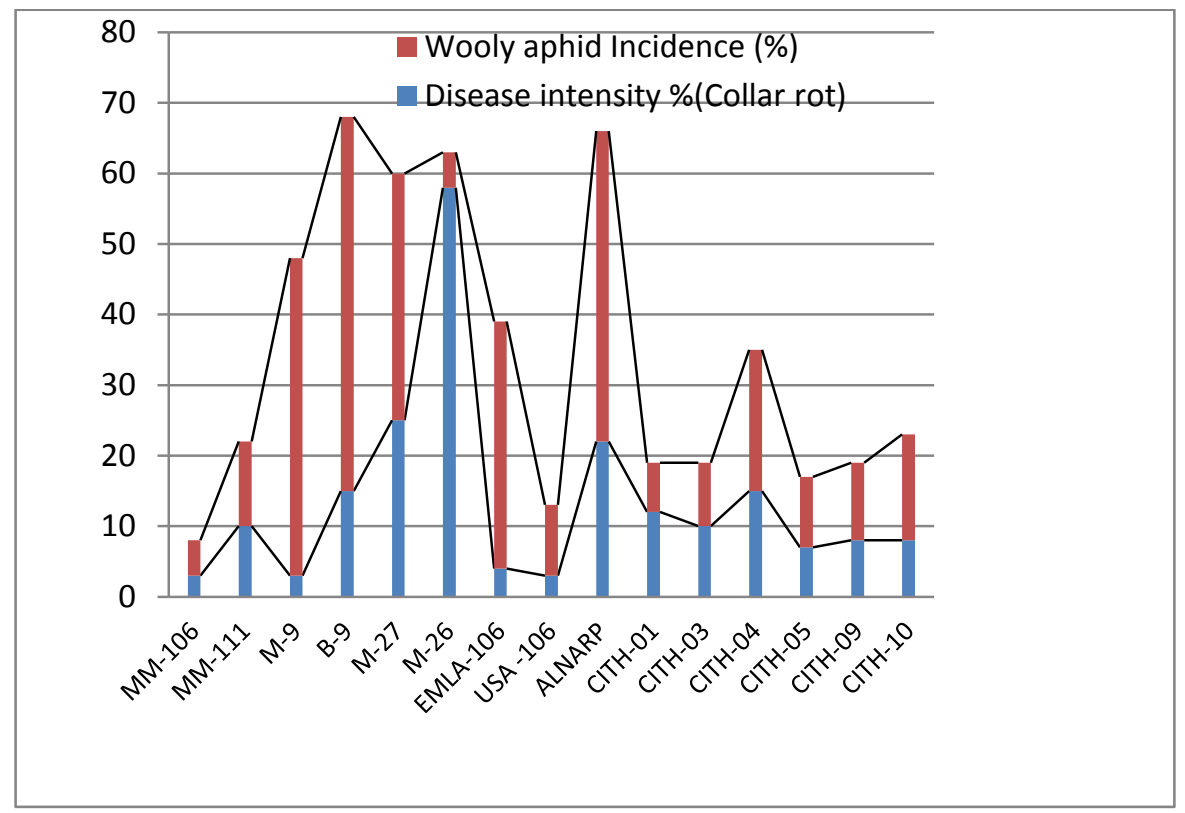

Figure 7. Screening of apple rootstocks for collar rot and wooly aphid Most of the apple rootstocks were having burr knot except CITH-Apple-Rootstock01, ALNARP and CITH-ARS-10. Similarly all the evaluated root stocks were having pink color petiole except B-9 in which dark red petiole observed. Leaf orientation in 
relation to the shoot have been grouped in 3 in most of the rootstocks have outward except B-9 (upward) and CITH-ARS-04 has upright type leaf attitude in relation to the shoot (Table 1). Burr knots are root initials that appear on the aboveground portion of the apple tree trunk. Some rootstocks, such as M.7, M.9, M.26, MM.106, and MM.111, are more prone to developing burr knots than others (Table 1). Conditions that favor burr knot development include low light, high humidity, and temperatures between $68^{\circ} \mathrm{F}$ and $95^{\circ} \mathrm{F}$. Burr knots are problematic; it can be an entry point for organisms, such as dogwood and plum borers, woolly apple aphids, fire blight bacteria and wood-rotting fungi. A tree with a heavy fruit load and many burr knots may produce weak growth or break during windy conditions.

Table1. Evaluation of apple rootstocks for different pomological traits

\begin{tabular}{l|lll}
\hline \multicolumn{1}{c}{ Rootstock } & Burr knot character & Petiole color & Leaf attitude to the shoot \\
\hline MM-106 & Present & Pink & Outward \\
MM-111 & Present & Pink & Outward \\
M-9 & Present & Pink & Outward \\
B-9 & Present & Dark red & Upward \\
M-27 & Present & Pink & Outward \\
M-26 & Present & Pink & Outward \\
EMLA-106 & Present & Pink & Outward \\
USA-106 & Present & Pink & Outward \\
ALNARP & Absent & Pink & Outward \\
CITH-01 & Absent & Pink & Outward \\
CITH-03 & Present & Pink & Outward \\
CITH-04 & Present & Pink & Upright \\
CITH-05 & Present & Pink & Outward \\
CITH-09 & Present & Pink & Outward \\
CITH-10 & Absent & Pink & Outward \\
\hline
\end{tabular}

Negative correlation of number of primary roots was found with number of secondary roots, whereas positive correlation was found with leaf area and leaf petiole length. Primary root length showed positive correlation with secondary root numbers, secondary root length and leaf petiole length but negative correlation with 
leaf area. Secondary root numbers were negatively correlated with secondary root length but positive correlated with leaf area and leaf petiole length. Whereas, secondary root length has exhibited negative correlation with leaf area and leaf petiole length and leaf area has showed positive correlation with leaf petiole length (Table 2). Rootstocks might be due to the variation in the genetic makeup of different genotypes.

Table 2. Correlation coefficient among different rootstock characters

\begin{tabular}{|c|c|c|c|c|c|c|}
\hline Characters & $\begin{array}{c}\text { Primary } \\
\text { root } \\
\text { numbers }\end{array}$ & $\begin{array}{l}\text { Primary root } \\
\text { length }(\mathrm{cm})\end{array}$ & $\begin{array}{l}\text { Secondary } \\
\text { root numbers }\end{array}$ & $\begin{array}{l}\text { Secondary } \\
\text { root length } \\
(\mathrm{cm})\end{array}$ & $\begin{array}{c}\text { Leaf area } \\
(\mathrm{cm} 2)\end{array}$ & $\begin{array}{l}\text { Leaf petiole } \\
\text { length }(\mathrm{cm})\end{array}$ \\
\hline Primary root numbers & 1.00 & -0.083 & 0.002 & $-0.699 *$ & $0.274^{*}$ & 0.020 \\
\hline Primary root length $(\mathrm{cm})$ & & 1.00 & $0.464^{*}$ & 0.052 & $-0.303 *$ & $0.499 *$ \\
\hline Secondary root numbers & & & 1.00 & -0.164 & $0.355^{*}$ & $0.402^{*}$ \\
\hline Secondary root length $(\mathrm{cm})$ & & & & 1.00 & $-0.361 *$ & -0.152 \\
\hline Leaf area $(\mathrm{cm} 2)$ & & & & & 1.00 & $0.264 *$ \\
\hline Leaf petiole length $(\mathrm{cm})$ & & & & & & 1.00 \\
\hline Leaf area $(\mathrm{cm} 2)$ & & & & & 1.00 & $0.264^{*}$ \\
\hline Leaf petiole length $(\mathrm{cm})$ & & & & & & 1.00 \\
\hline
\end{tabular}

*significant at $5 \%$ level of significant

\section{DISCUSSION}

Usually the origin and development of the adventitious roots take place endogenously next to and just outside the central core of vascular tissue, many easy to root woody plant species develop adventitious roots from phloem ray parenchyma cells (Hartmann et al., 1993) further, auxin hormones promotes root length by influencing the synthesis of enzymes concerned in cell enlargement (Wada et al., 1998). The variation in root numbers in different rootstocks is due to difference in indigenous level of plant hormones in these rootstocks. Variation in length of roots recorded in this research activity is aligned with the results $(6.7$ to $19.6 \mathrm{~cm})$ reported by (Tripathi et al. (2006). The difference in primary and secondary root numbers and their length might be due to the different genetic make-up. Srivastava et al. (2006) reported profuse rooting in MM-.106 rootstock. Tripathi et al. (2006) observed 9-25 roots per stool in MM-106, MM-109, M-9 and M-4 rootstocks in contrast less number of average roots were recorded in the Malus baccata genotypes through cutting. Mitra (1991) also reported profuse rooting in Malling Merton rootstocks of apple which are in accordance to the results of this research activity. In general Malus baccata strains are hard to roots. The variation in the leaf areas in the different kind 
of In contrast, Khatic and Sharma (2013) reported leaf area in the Merton-793 rootstock $9.77 \mathrm{~cm}^{2}$ which is very high as compared to evaluated rootstocks. The exotic rootstocks namely MM- 106, MM-111, are least affected to collar rot and wooly aphid, these results in line of findings reported by Rock and Zeiger (1974) who observed that the wooly aphid in MM series rootstocks have no galls formations and are fully resistant to wooly aphid infestation and also the crab apple rootstocks are least affected by wooly aphid and collar rot infections.

\section{CONCLUSION}

On the basis of the results obtained it can be concluded that the CITH-AR selections have better superiority to exotic Malling rootstocks for better suitability to climatic conditions of the North Western Himalayan regions of Kashmir. For raising the HDP on Malling rootstock, assured irrigations are required unlike in crab apple root stock, further the crab apple seeds are easily available and have high germination ability.

\section{REFERENCES}

Anonymous. 2014. Guidelines for the conduct of test for distinctiveness Uniformity and stability on apple (Malus x domestica Borkh).www.plantauthority.gov.in.

Anonymous. 2014. Indian Horticulture Data Base, 2014. Published by NHB, MOA, GOI, Gurgaon. pp. 26-33

Anonymous. 2016.www.plantauthority.gov.in.

Khatik, P. C. and Sharma, D. D. 2013. Effect of IBA and NAA on stool layering in apple clonal root stock, Merton 793. Progressive Horticulture, 45(2): 388-391

Mita, S. K.1991. Apple. In: Temperate Fruits (Eds. Mitra, S. K.; Rathore, D. S., Bose, T. K. Horticulture and Allied Publication. Calcutta, 1-122

Rock, G. C., Zeiger, D. C. 1974.Woolly apple aphid infests Malling and Malling-Merton rootstocks in propagation beds in North Carolina. Journal of Economic Entomology, 67 (1): $137-138$

Salisbury, F. B. and Ross, C. W. 2005. In Plant Physiology. $3^{\text {rd }}$ Edition. CBS Publishers and Distributers. Delhi. pp. 309-329

Srivastava, K. K., Bhat, K. M., Sharma, M. K. and Nazki, T. T. 2006. Studies on multiplication of MM 106 rootstock of apple through trench layering in Kashmir Valley. Research on Crops, 7 (1): 311-312

Taiz, Lincoln. and Zeiger, Eduardo. 2006. Plant Physiology. $4^{\text {th }}$ edition. Sinauer Associates Inc Publisher. pp. 84-86

Tripathi, P. C., Verma, M. K., Verma, R. K., Pandey, G. and Sofi, A. A. 2006. Response of NAA and root initiation and growth in apple root stocks. Indian Journal of Horticulture, 63(1):81-82 
Wada, S., Tanimoto, E. and Masuda, Y. 1998. Cell elongation and metabolic turnover of the cell wall as affected by auxin and cell wall degrading enzymes. Plant Cell Physiology, 9(2): 369-376

Wolf, dwight E., Strang ohn g., and Wright, Shawn. 2011. Rootstocks for kentucky fruit trees, horticulture cooperative extension service. University of Kentucky College of Agriculture, lexington, Ky, 40546 